\title{
Assessment of Agricultural Mechanization Indicators for Central Agro- Climatic Zone of Uttar Pradesh, India
}

\author{
Tarun Kumar Maheshwari* and Ashok Tripathi
}

Farm Machinery and Power Engineering, VSAET, Sam Higginbottom University of Agriculture, Technology and Sciences (SHUATS), Allahabad-211 007, UP, India

*Corresponding author

Keywords

Mechanization index, Power Availability, Total energy, Mechanical Energy, Cropping Intensity

Article Info

Accepted:

10 April 2019

Available Online:

10 May 2019

\section{A B S T R A C T}

Uttar Pradesh is situated in northern India. It covers $243290 \mathrm{Km}^{2}$. The state is also divided into 9 agro-climatic zones. The central agro-climatic zone of Uttar Pradesh contains 14 districts. Out of 14 districts 4 districts were selected for the study Agriculture mechanization also helps in improving safety and comfort of the agricultural worker, improvements in the quality and value addition of the farm produce and also enabling the farmers to take second and subsequent crops making Indian agriculture more attractive and profitable. There is a linear relationship between availability of farm power and farm yield. In India, there is a need to increase the availability of farm power from $2.02 \mathrm{~kW}$ per ha (2016-17) to $4.0 \mathrm{~kW}$ per ha by the end of 2030 to cope up with increasing demand of food grains. The average size of operational holding has declined to 1.08 ha in 2015-16 as compared to 1.15 in $2010-11$. The farm mechanization indicators and their variability among different districts of central zone were studied. It can be seen that Kannauj and Pratapgarh are significantly more mechanized in comparison to Hardoi and Etawah on the basis of mechanization index and power availability. Also, power availability of Kannuj is significantly highest in comparison to other 3 districts. The Mechanization index, Power availability, Total energy, Mechanical energy, are highest in Kanuuj district significantly in comparison to Hardoi, Etawah and Pratapgarh ie 0.972, $3.29 \mathrm{~kW} / \mathrm{ha}, 4901.40 \mathrm{kWh} / \mathrm{ha}$, and $4810.67 \mathrm{kWh} /$ ha respectively but Human energy is highest in Hardoi district i.e. $897.75 \mathrm{kWh} / \mathrm{ha}$ in comparison to other three districts. The cropping intensity of Kannuj district is $260 \%$ which is less than Hardoi but more than Etawah and Pratapgarh. The average value of Mechanization index, Power availability, Total energy, Mechanical energy in central zone of UP are $0.9497,2.18 \mathrm{~kW} / \mathrm{ha}, 2450 \mathrm{kWh} / \mathrm{ha}, 2351.86 \mathrm{kWh} / \mathrm{ha}$, $97.89 \mathrm{kWh} /$ ha respectively

\section{Introduction}

Uttar Pradesh is situated in northern India. It covers $243290 \mathrm{Km}^{2}$. This is most populous state of India. It is the fifth largest state of
India. It accounts for 6.88 percent of total area of the country. The population of the state was about 200 million as per census of 2011, which accounted for 16.49 percent of the total population of India. Uttarakhand was also a 
part of Uttar Pradesh till November, 2000. The state is divided into 4 divisions, namely. Western (28 districts), Eastern (28 districts), Central (14 districts) and Bumdelkhand (7 districts). At present state have 75 districts, 327 tehsils, 822 blocks and 107452 revenue villages. The state is also divided into 9 agro climatic zones, 1. Tarai Region 2. Western Plain Region) 3. Central Western Region 4. South Western Region 5. Central Plain Region 6. Bundelkhand Region 7. North Eastern Plain Region 8. Eastern Plain Region 9. Vindhyachal Region.

Agriculture Mechanization is an essential input to modern agriculture to increase the productivity and for making judicious use of other inputs like seeds, fertilizers, chemicals $\&$ pesticides and natural resources like water, soil nutrients etc. besides reducing the human drudgery and cost of cultivation. Agriculture Mechanization also helps in improving safety and comfort of the agricultural worker, improvements in the quality and value addition of the farm produce and also enabling the farmers to take second and subsequent crops making Indian agriculture more attractive and profitable. It also helps the Indian farming to become commercial instead of subsistence. The small and marginal holdings taken together (0.00-2.00 ha) constituted $86.21 \%$ in 2015-16 against $84.97 \%$ in 2010-11. Semi-medium and Medium operational holdings (2.00-10.00 ha) in $2015-16$ were only $13.22 \%$ with $43.61 \%$ operated area. The large holdings (10.00 ha \& above) were merely $0.57 \%$ of total number of holdings in 2015-16 and had a share of 9.04\% in the operated area as against $0.71 \%$ and $10.59 \%$ respectively for $2010-11$ census. There is a linear relationship between availability of farm power and farm yield. Therefore, there is a need to increase the availability of farm power from $2.02 \mathrm{~kW}$ per ha (2016-17) to $4.0 \mathrm{~kW}$ per ha by the end of 2030 to cope up with increasing demand of food grains. The average size of operational holding has declined to 1.08 ha in $2015-16$ as compared to 1.15 in $2010-11$.

Zangeneh et al., (2010) defined Mechanization Index (MI) and Level of Mechanization (LOM), to characterize farming system of potato in the Hamadan province of Iran. These indicators are defined mathematically as equations (1) and (2) respectively. The MI elaborated here is an expression of the deviation of the actual amount of motorized farm work from the normal values at the regional level.

$$
M I=\frac{1}{n} \sum_{i=1}^{n} \frac{M_{a(i)}}{M_{a v}} * \frac{L_{i}}{T L_{i}} \ldots \text { (1) }
$$

Where, MI = Mechanization Index for the production unit 'a',

Me (i) = Overall input energy due to machinery in the production unit 'a',

Mav = Regional-average energy due to machinery,

$\mathrm{Li}=$ Land area cultivated in the production unit 'a',

Tli $=$ Total farm land ownership of production unit 'a',

$\mathrm{n}=$ Number of farms.

The MI index, proposed by Andrade and Jenkins, 2003 is an indication of the amount of machinery a given farmer uses for farm work compared with the average in the region. The second term in Equation (1) includes a ratio between the land area cultivated with soybean crop and the total land ownership. This term was introduced because it reflects the importance of land demand for cultivation. The LOM index is based on the premise that a mechanized farmer is the one that finds a way to utilize amounts of mechanical energy that are higher than the typical values using locally available technology. 
$\boldsymbol{L O M}=\sum_{i=1}^{n} \frac{\boldsymbol{P}_{i} * \boldsymbol{\eta}}{L_{i}} \cdots(2)$

Where, LOM = level of mechanization,

$\mathrm{Pi}=$ power of tractors,

$\eta=$ correction factor for utilized power $(0.75)$.

Field capacity was multiplied by rated power so the quantification of energy expenditure was made in work units $(\mathrm{kWh})$. The regional normal will be obtained after compiling a full dataset of all respondents and then it would be defined the mode for the number of passes for each operation as well as the mode in tractor size and field capacity.

The level of mechanization is calculated by the following formula (Almasi et al., 2000).

Mechanization level

$(h p / h a)=\frac{\text { Total Power }}{\text { Cultivated Area }} \cdots$

The Total power of existing tractors $(\mathrm{hp})=$ Average nominal power of one tractor $x$ Number of working tractors.

Total real power of tractors $=$ Total power of existing tractors $\mathrm{x}$ Conversion coefficient (0.75).

Animal energy $(\mathrm{hp}-\mathrm{h})=$ Total existing animal power $x$ Annual functional hours.

Annual functional hours $=$ Number of functional days $\mathrm{x}$ Mean functional hours during a day.

Total existing animal power $(\mathrm{hp})=$ Produced power of animal $x$ Number of animals.

Human energy (hp-h) can also be calculated in the same manner.

\section{Materials and Methods}

After selection of variables, a questionnaire was prepared to collect primary data from Etawah, Kannuj, Hardoi and Pratapgarh districts of central Uttar Pradesh. A Stratified Multistage Sampling Design was applied considering district and village as strata. The villages were selected from four mentioned districts of central zone of Uttar Pradesh using random sampling and 4 districts out of 14 district of central zone were taken for the study. Then from each district, 5 villages and then from each villages, 10 farmers were selected using random sampling. Primary data were collected from 200 farmers from 20 villages of 4 districts i.e. 50 farmers from each district. As mechanization is a multidimensional concept, thus the following indices were evaluated to study the mechanization status in target region. To study the mechanization status of four districts of Central zone of Uttar Pradesh The many variables were selected based on requirements to estimate degree of mechanization, level of mechanization (Power availability), mechanization index, cropping intensity, irrigation intensity, input cost and farmers Income. The following variables were selected:

\section{Degree of mechanization (MD)}

It is one of the quantitative measure of mechanization, by which the degree of mechanization of different operations in a cropping system like land preparation, sowing, weeding, irrigation, spraying, harvesting, threshing, transportation of agricultural produce and etc. can be assessed. It is the ratio of mechanization area accomplished to the area to be mechanized (Almasi et al., 2000). The degree of mechanization of particular implements used in a particular agricultural operation can be given as:

Degree of Mechanization $=$ Mechanized area/Area to be Mechanized...,(4)

In other words, the degree of mechanization can be used to evaluate the extent of different agricultural operations performed using machinery or improved implements to the 
operations performed by humans, animals or traditional implement i.e. Area under bullocks, cultivator, power tiller, disc plough, M B plough, deshi hal (local plough), seed cum fertilizer drill, diesel engine, electric pump, sprinkler, dripper, sprayer (manually operated), sprayer (tractor operated), manual harvesting, thresher and combine harvester.

\section{Level of mechanization (power availability or farm power)}

Farm power is an essential input in agricultural production system to operate different types of equipment for timely field completion of agricultural works to increase productivity and maintain sustainability of farm. The mobile power is used for different field jobs like land preparation, sowing, weeding, spraying, and harvesting etc., whereas stationary power is used for lifting water, operating irrigation equipment, threshing, cleaning and grading of agricultural produce. The main sources of mobile power are human, draught animal, tractors, power tiller and self-propelled machines (combines, dozers, reapers, sprayers and etc.) where as the source of stationary power is oil engines and electric motors. In this study, power availability was also evaluated for 4 districts of Uttar Pradesh. The main sources of mobile power were human, draught animal, tractors and combines whereas the sources of stationary power were oil engines, electric motors and threshers in the 4 districts. The power availability was evaluated using formula given by Eq. 5 .

Power availability $(\mathrm{hp} / \mathrm{ha})=$ Total Power/Net Cultivated Area...(5)

Where, Total power $=$ Total mobile power + Total stationary power

Net Cultivated Area $=$ Net Cultivated Area of Target Region Villages wise number of tractor, combine harvester, bullocks, agricultural workers, power tiller, diesel engines and electric pump power are human, draught animal, tractors, power tiller and selfpropelled machines (combines, dozers, reapers, sprayers and etc.) where as the source of stationary power is oil engines and electric motors. In this study, power availability was also evaluated for Etawah district of Uttar Pradesh. The main sources of mobile power were human, draught animal, tractors and combines whereas the sources of stationary power were oil engines, electric motors and threshers in the Etawah District. The power availability was evaluated using formula given by Eq. 6 .

Power availability $(\mathrm{hp} / \mathrm{ha})=$ Total Power/ Net Cultivated Area...(6)

Where, Total power $=$ Total mobile power + Total stationary powerNet Cultivated Area $=$ Net Cultivated Area of Target Region Villages wise number of tractor, combine harvester, bullocks, agricultural workers, power tiller, diesel engines and electric pump

\section{Mechanization index (MI)}

Farm operation wise mechanization index is one of the quantitative measures of mechanization and it can be defined as per capita power in terms of hp per hectare for a particular region. Evaluation of operation wise mechanization index first then Farmers wise human power, animal power and machinery power availability like tractor, thresher, combine. In this study, a new approach to evaluate Mechanization Index was used to overcome the demerits in the previous methodology to evaluate Mechanization Index and is given below:

$$
\begin{aligned}
& M I i \quad r s \\
& =\quad\left(\sum \sum M^{p} j k \times M^{t} j k\right) / \\
& \\
& \quad=1 \\
& \quad=1 k
\end{aligned}
$$




$$
\begin{aligned}
& r \quad{ }^{s}\left(M \times M_{j k}^{t}+H^{p}{ }_{j k} \times M\right. \\
& \Gamma^{\sum} \sum_{j k}^{p}{ }_{j k}^{t}+ \\
& j=1 \\
& l
\end{aligned}
$$

Where,

$\mathrm{MI}_{\mathrm{i}}=$ Mechanization Index of ith farm

$\mathrm{M}^{\mathrm{p}}{ }_{\mathrm{jk}}=$ Power of machine used in kth operation in $\mathrm{j}$ th crop (including stationary and movable)

$\mathbf{M}_{\mathrm{jk}}^{\mathrm{t}}=$ Time taken by machine to perform kth operation in jth crop $\mathrm{H}_{\mathrm{jk}}^{\mathrm{p}}=$ Power of human used

in kth operation in jth crop (including stationary and movable)

$\mathrm{H}_{\mathrm{jk}}^{\mathrm{t}}=$ Time taken by human to perform kth operation in jth crop

$\mathrm{A}^{\mathrm{p}_{\mathrm{jk}}}=$ Power of animal used in kth operation in jth crop (including stationary and movable)

$\mathrm{A}_{\mathrm{jk}}^{\mathrm{t}}=$ Time taken by animal to perform kth operation in jth crop

$\mathrm{i}=1$ to $n$, where $n$ is number of farm $\mathrm{j}=1$ to

$r$, where $r$ is number of crop cultivated in a calendar year $k=1$ to $\mathrm{s}$, where $s$ is no of farm practices in jth crop

\section{Results and Discussion}

The graphical representation of variation of Mechanization index, Power availability, Total energy, Human energy, Mechanical energy, Degree of mechanization, Cropping intensity, Irrigation intensity, Farmers income and Input cost in four districts i.e. Kannuj, Hardoi, Etawah, Pratapgarh are shown in figure from 1 to 12 . The farm mechanization indicators and their variability among different districts of central agro climatic zone were studied. It was observed that all the mechanization indicators varied significantly among districts as $\mathrm{p}<0.05$ (Table 1). The comparisons of indicators for different districts have been performed using LSD values and presented in (Table 2). It can be seen that Kannauj and Pratapgarh are

\begin{tabular}{|c|c|c|c|c|c|c|}
\hline Source & DF & p-values & & & & \\
\hline Model & 3 & $\begin{array}{l}\text { Mechanization } \\
\text { Index }\end{array}$ & $\begin{array}{l}\text { Total } \\
\text { Energy }\end{array}$ & $\begin{array}{l}\text { Human } \\
\text { Energy }\end{array}$ & $\begin{array}{l}\text { Mechanical } \\
\text { Energy }\end{array}$ & $\begin{array}{l}\text { Power } \\
\text { availability }\end{array}$ \\
\hline Error & 8 & $<.0001$ & 0.0090 & $<.0001$ & 0.0089 & 0.0154 \\
\hline Total & 11 & - & - & - & - & - \\
\hline $\mathbf{R}^{2}$ & - & 0.930625 & 0.747170 & 0.964072 & 0.747449 & 0.709103 \\
\hline CV & - & 0.998967 & 54.06511 & 19.38278 & 55.49522 & 22.37329 \\
\hline
\end{tabular}
significantly more mechanized in comparison to Hardoi and Etawah on the basis of mechanization index and power availability.

Table.1 ANOVA for mechanization indicators

Table.2 Comparison of mechanization indicators

\begin{tabular}{|l|l|l|l|l|l|}
\hline & \multicolumn{3}{|l|}{ District } & LSD \\
\hline Indicators & Kannuj & Hardoi & Etawah & Pratapgarh & - \\
\hline Mechanization Index & $0.972 \mathrm{a}$ & $0.968 \mathrm{~b}$ & $0.942 \mathrm{c}$ & $0.97 \mathrm{a}$ & 0.0179 \\
\hline Total Energy $(\mathbf{k W h} / \mathbf{h a})$ & $4901.40 \mathrm{a}$ & $897.75 \mathrm{~d}$ & $1250.69 \mathrm{c}$ & $2749.20 \mathrm{~b}$ & 2882.7 \\
\hline Human Energy(kWh/ha) & $90.73 \mathrm{bc}$ & $897.75 \mathrm{~b}$ & $50.95 \mathrm{~d}$ & $226.32 \mathrm{a}$ & 33.876 \\
\hline Mechanical Energy(kWh/ha) & $4810.67 \mathrm{a}$ & $874.17 \mathrm{~d}$ & $1199.74 \mathrm{c}$ & $2522.88 \mathrm{~b}$ & 2861.9 \\
\hline Power Availability (kW/ha) & $3.29 \mathrm{a}$ & $1.72 \mathrm{c}$ & $1.53 \mathrm{~d}$ & $2.21 \mathrm{~b}$ & 1.0167 \\
\hline
\end{tabular}



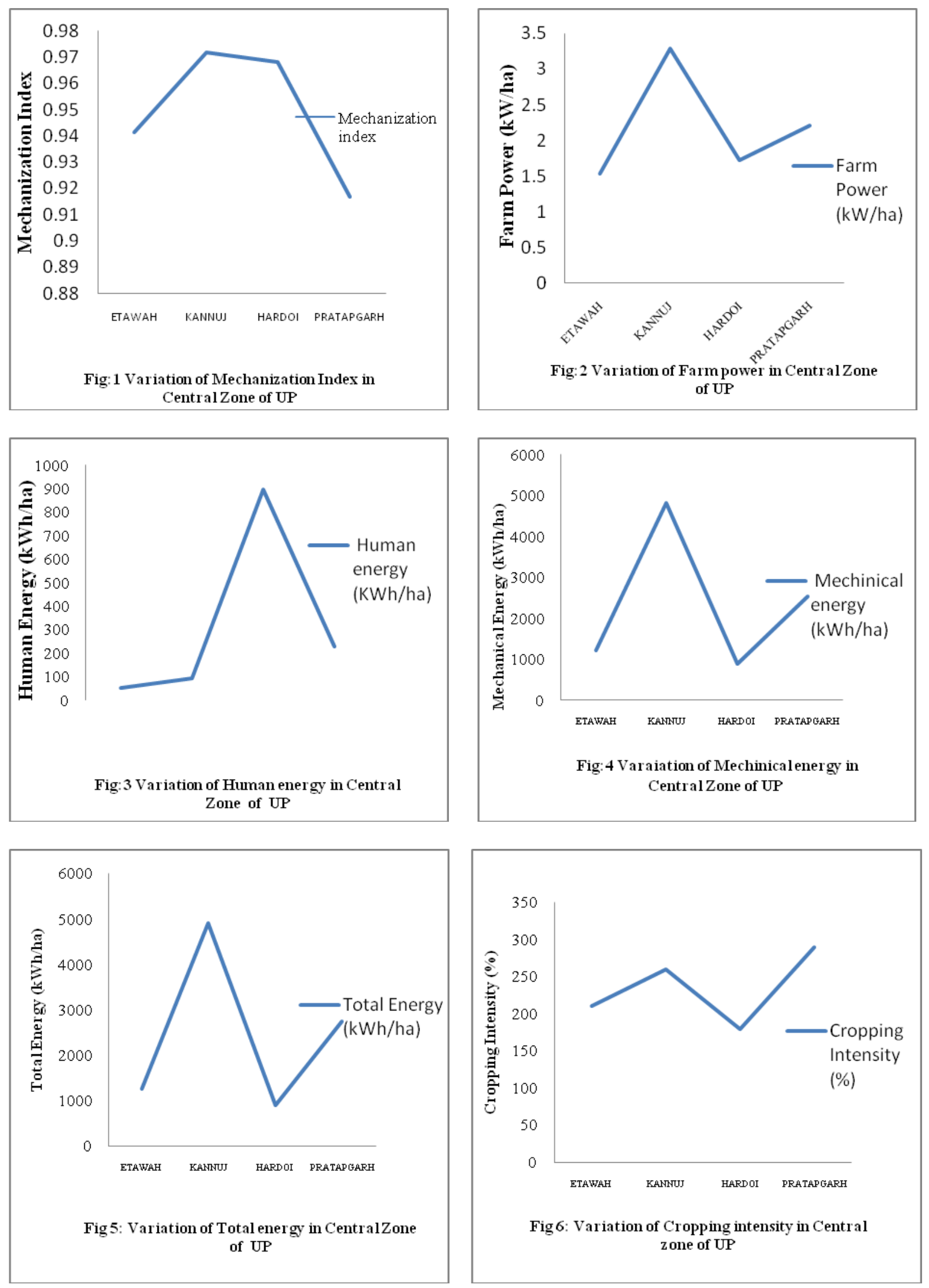


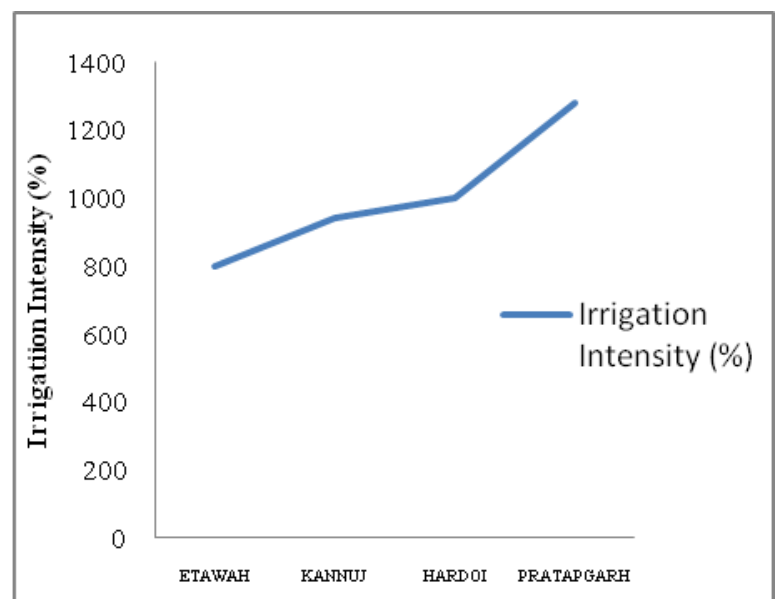

Fig. 7: Variation of Irrigation intensity in Central Zone in UP

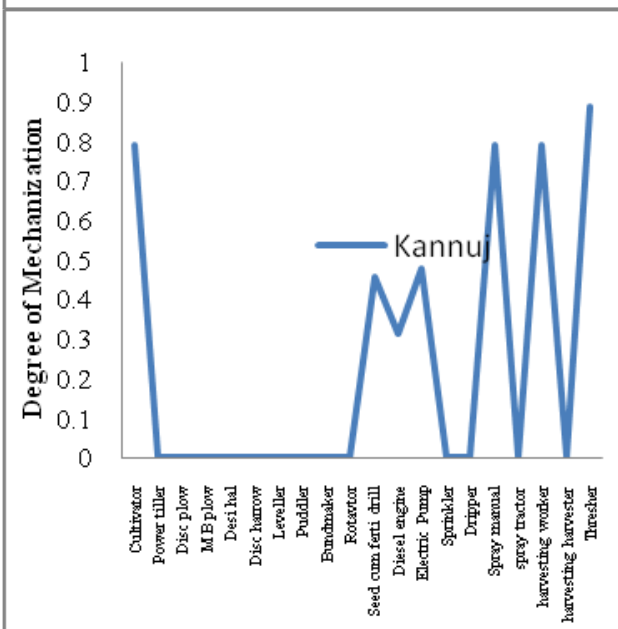

Fig 9: Variation of Degree of Mechaniz ation in Kannuj

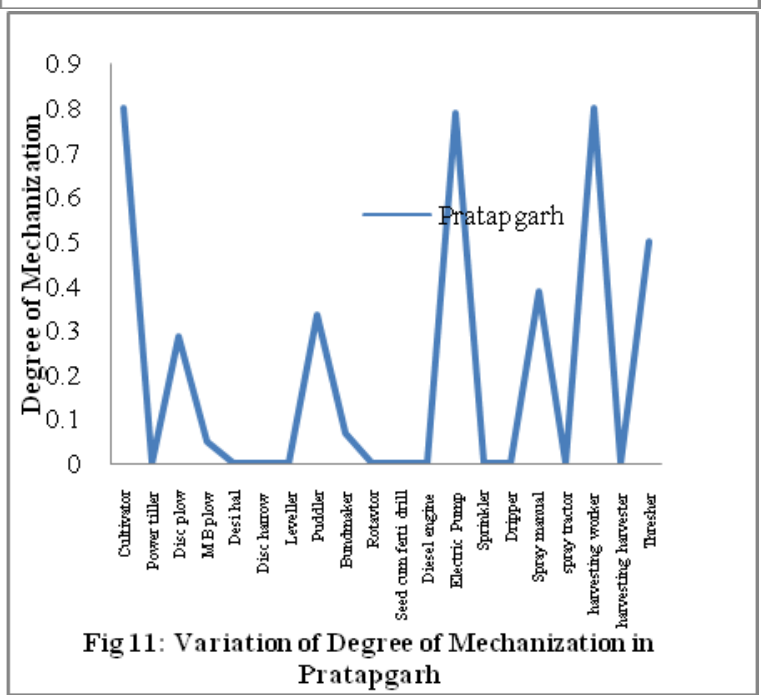

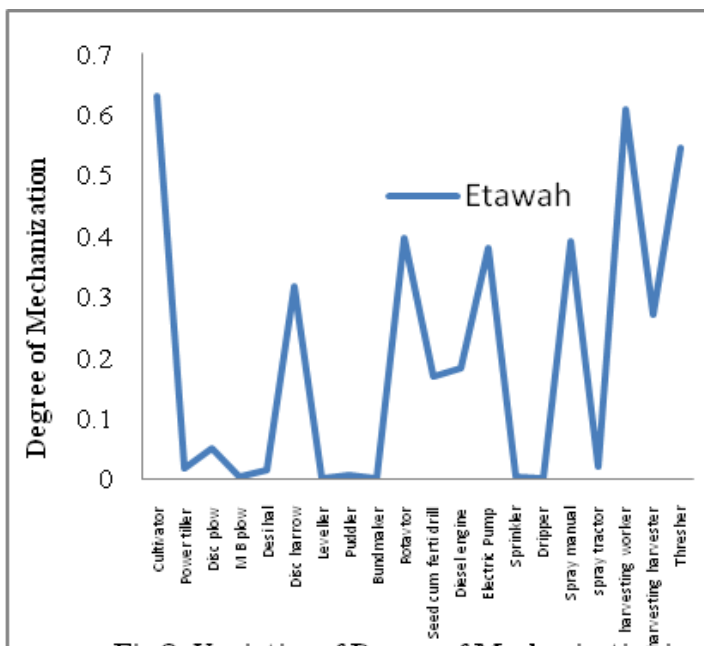

Fig.8: Variation of Degree of Mechaniz ation in Etawah

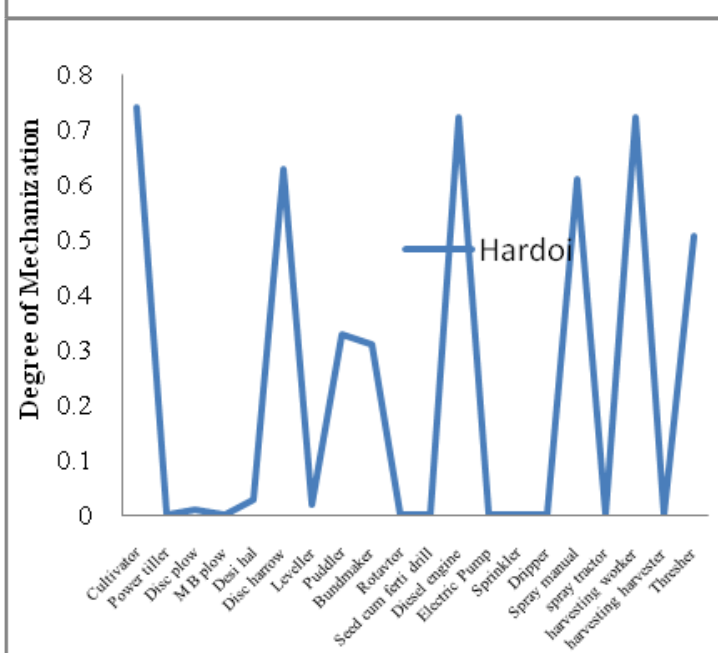

Fig 10: Variation of Degree of Mechanization in Hardoi

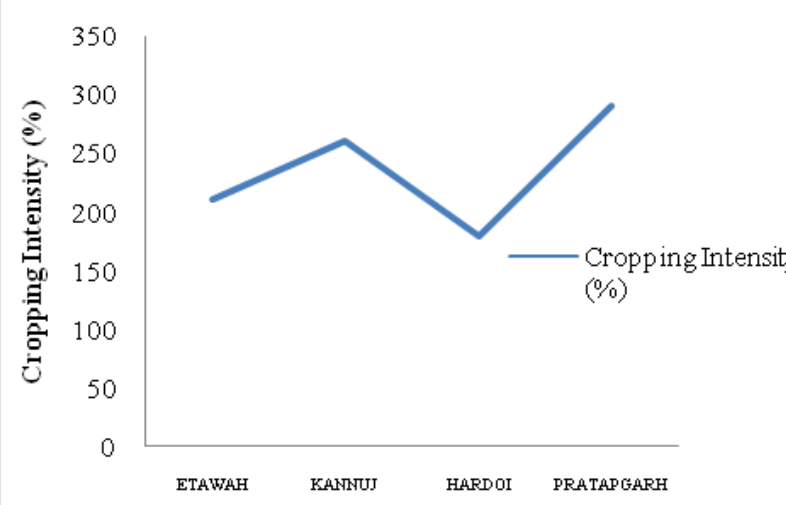

Fig: 12 Variation of Cropping intensity in Central zone of UP 
Also, power availability of Kannuj is significantly more in comparison to other 3 districts. The comparison of other mechanization indicators can be observed in Table 2 .

In conclusion, the Mechanization index, Power availability, Total energy, Mechanical energy, are highest in Kanuuj district significantly in comparison to Hardoi, Etawah and Pratapgarh i.e. $0.972,3.29 \mathrm{~kW} / \mathrm{ha}$, $4901.40 \mathrm{kWh} / \mathrm{ha}$, and $4810.67 \mathrm{kWh} / \mathrm{ha}$ respectively but Human energy is highest in Hardoi district in comparison to other three districts. The average value of Mechanization index, Power availability, Total energy, Mechanical energy in central zone of UP are 0.9497, $2.18 \mathrm{~kW} / \mathrm{ha}, 2450 \mathrm{kWh} / \mathrm{ha}, 2351.86$ $\mathrm{kWh} / \mathrm{ha}, 97.89 \mathrm{kWh} / \mathrm{ha}$ respectively. The cropping intensity of Kannuj district is $260 \%$ which is less than Hardoi but more than Etawah and Pratapgarh.

\section{References}

1. Anonymous. 2018. Agriculture Census 2015-16 (Phase I) Provisional Results, Department of Agriculture, Cooperation \& Farmers Welfare, Government of India (GOI). Report of Agriculture census 2015-16

2. Anonymous. 2018. Annual Report 201718, Department of Agriculture, Cooperation \& Farmers Welfare, Ministry of Agriculture and Farmers Welfare, Government of India, New Delhi, 93 p.

3. Roy Ramendu and Hasib Ahmad, 2015: State Agricultural Profile of Uttar Pradesh. Report of Agriculture profile 2014-15.

4. Almasi, M., S. Kiani, and N. Loui-mi. 2000. Principles of Agricultural Mechanization. Ma soumeh (PBUH) Publication. Ghom, Iran. PP. 19-40.

5. Gifford, R. C., and A. G. Rijik. 1980.
Guidelines for Agricultural mechanization strategy in development. Economic and Social Commission for Asia and the Pacific (ESCAP), Regional Network for Agricultural machinery.

6. Morris, J. 1985. The economics of small farm mechanization. In 'Small Farm Mechanization for Developing Countries' (eds P. Crossley and Kilgour), pp. 171-184, John Wiley and Sons: New York.

7. Nowacki, T. 1978. Methodology used by ECE Countries in fore-casting mechanization developments. United Nations Economic Commission for Europe, AGRI/ MECH Report No. 74.

8. Nowacki, T. 1984. Changes and trends in the quantity and balance of energy consumption in agriculture (general methodology). FAO/ECE/AGRI/ MECH Report, No. 105, Geneva p. 36.

9. Andrade, P. and B. Jenkins, 2003. "Identification of Patterns of Farm Equipment Utilization in Two Agricultural Regions of Central and Northern Mexico". Agricultural Engineering International: the CIGR Journal of Scientific Re-search and Development. Invited Overview Paper. Vol. V. June 2003.

10. Ramirez, A. A., A. Oida, H. Nakashi-ma, J. Miyasaka, and K. Ohdoi. 2007. Mechanization index and machinery energy ratio assessment by means of an Artificial Neural Network: A Mexican case study. Agricultural Engineering International. Manuscript PM 07002, 2.

11. Rijk, A. G. 1989. Agricultural mechanization policy and strategy- the case of Thailand. Asian Productivity Organization, Tokyo, Japan.

12. Singh, G. and D. De. 1999. Quantification of a mechanization indicator for Indian agriculture. Applied Engineering in Agriculture, 15(3): 197-204.

13. Singh, G. 2006. Estimation of a 
mechanization index and its impact on production and economic factors- A case study in India. Bio-systems Engineering, 93(1): 99-106.

14. Zangeneh, M., M. Omid, and A. Akram.
2010. Assessment of agricultural mechanization status of potato production by means of Artificial Neural Network model. Australian Journal of Crop Science, 4(5): 372-377.

\section{How to cite this article:}

Tarun Kumar Maheshwari and Ashok Tripathi. 2019. Assessment of Agricultural Mechanization Indicators for Central Agro-Climatic Zone of Uttar Pradesh, India. Int.J.Curr.Microbiol.App.Sci. 8(05): 725-733. doi: https://doi.org/10.20546/ijcmas.2019.805.085 